\title{
HADIS MATERI PENDIDIKAN
}

\author{
Aini Indah Dwi Cahyani, dan Nadra Ulfa \\ aini.indah13@mhs.uinjkt.ac.id
}

Abstrak: Pendidikan adalah pembelajaran pengetahuan, keterampilan, dan kebiasaan sekelompok orang yang diturunkan dari satu generasi ke generasi berikutnya melalui pengajaran, pelatihan, atau penelitian. Pendidikan sering terjadi di bawah bimbingan orang lain, tetapi juga memungkinkan secara otodidak. Setiap pengalaman yang memiliki efek formatif pada cara orang berpikir, merasa, atau tindakan dapat dianggap pendidikan. Pendidikan umumnya dibagi menjadi tahap seperti prasekolah, sekolah dasar, sekolah menengah dan kemudian perguruan tinggi, universitas atau magang. Terdapat beberapa materi pendidikan yang sangat penting untuk diajarkan kepada peserta didik. Materi-materi tersebut di antaranya adalah pendidikan akidah, Al-Qur'an, fiqih, ibadah, dan keterampilan.

Kata Kunci: Hadis, Materi Pendidikan, Islam

\section{A. Pendahuluan}

Pendidikan adalah pembelajaran pengetahuan, keterampilan, dan kebiasaan sekelompok orang yang diturunkan dari satu generasi ke generasi berikutnya melalui pengajaran, pelatihan, atau penelitian. Pendidikan sering terjadi di bawah bimbingan orang lain, tetapi juga memungkinkan secara otodidak. Setiap pengalaman yang memiliki efek formatif pada cara orang berpikir, merasa, atau tindakan dapat dianggap pendidikan. Pendidikan umumnya dibagi menjadi tahap seperti prasekolah, sekolah dasar, sekolah menengah dan kemudian perguruan tinggi, universitas atau magang. 
Berkaitan dengan materi pengajaran pada pembahasan kali ini, hadits tarbawi dengan sub pembahasan "Materi Pengajaran" akan menjelaskan hadis-hadis yang berkaitan dengan dunia pendidikan, khususnya pendidikan dan pengajaran.

\section{B. Materi Pendidikan Akidah}

\section{Hadis Materi Pendidikan Akidah}

Dalam suatu hadis yang diriwayatkan oleh Ibnu Abbas ra, bahwa Rasulullah Saw. bersabda:

عن ابنِ عباسٍ رضي الله عنهما ، قَالَ : كنت خلف النَّيّ - صلى الله عليه وسلم

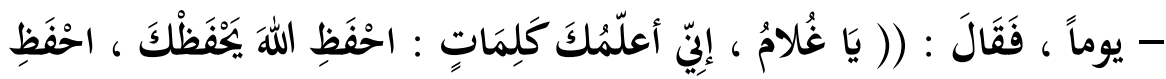

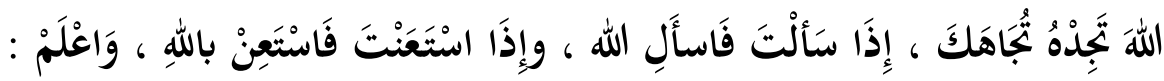



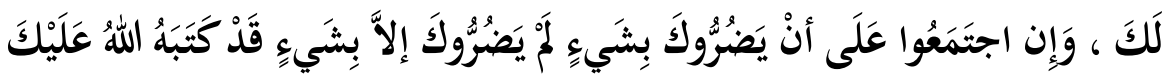

$$
\text { رُرِفَتِّ الأَقْلامُ وَجَفَّتِ الصُّحفُ (رواه الترمذي) ، وَقالَ : (( حديث حسن }
$$

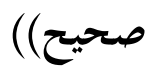

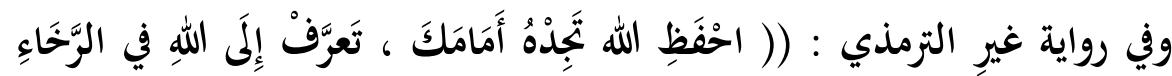

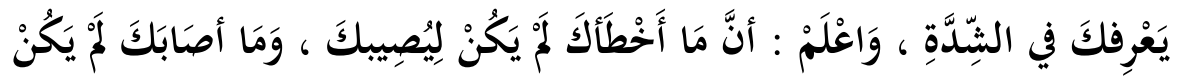

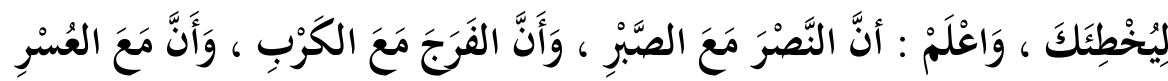

Dari Ibnu Abbas ra, ia berkata: "Kali tertentu saya berada dibelakang Nabi Saw, kemudian beliau bersabda "Hai anak kecil, aku akan mengajarkan kepadamu nbeberapa kalimat, yaitu: "Jagalah (perintah) Allah niscaya kamu dapati Allah selalu di hadapanmu. Jika engkau minta, mintalah kepada Allah, dan jika engkau meminta pertolongan, maka mintalah pertolongan kepada Allah. Dan ketahuilah, jika umat manusia 
bersatu untuk memberikan manfaat (kebaikan) kepadamu niscaya mereka tidak akan dapat melakukan hal itu kepadamu kecuali dengan sesuatu hal yang telah ditentukan Allah padamu. Dan jika mereka bersatu hendak mencelakakan dirimu niscaya mereka tidak akan dapat mencelakakanmu kecuali dengan sesuatu yang telah ditentukan Allah padamu. Telah diangkat pena dan telah keringlah (tinta) lembaran-lembaran itu". (HR. Imam Tirmidzi $)^{2}$

Dan dalam riwayat selain Tirmidzi dikatakan, Rasulullah saw bersabda: "Peliharalah (perintah) Allah niscaya engkau akan menemui-Nya dihadapanmu. Hendaknya engkau mengingat Allah di waktu lapang (senang, niscaya Allah akan mengingatmu diwaktu susahmu. Ketahuilah, sesungguhnya sesuatu yang seharusnya luput mengenaimu, tentulah sesuatu itu tidak akan mengenaimu. Ketahuilah, sesungguhnya kemenangan itu disertai kesabaran, kesenangan itu ada kesudahan, dan sesudah kesulitan, pasti ada kemudahan.

\section{Kandungan dan Penjelasan Hadits serta Kaitannya dengan Dunia Pendidikan}

Hadits ini mengandung penjelasan tentang aqidah Islam. Rasul menyampaikan pelajaran ini kepada Abdullah ibn 'Abbas pada usia mudanya. Ini menunjukkan bahwa pendidikan aqidah sudah ditanamkan kepada seseorang sejak ia kecil. Karena usia inilah yang paling tepat untuk menanamkan nilai. Bila nilai itu sudah tertanam, maka kehidupan setelah dewasa dan masa tua banyak dipengaruhi oleh masa muda itu. Sehingga kalaupun seseorang hidup di lingkungan yang sangat jauh dari ajaran Islam, tetapi ideologinya tidak terpengaruh, keyakinannya tidak goyah. Adapun jika penanaman nilai itu terlambat, apalagi setelah kepalanya terisi oleh teori-teori dan doktrin di luar Islam, maka manusia seperti inilah susah untuk disadarkan dan dibimbing ke jalan Islam. ${ }^{3}$

Sayangnya di masyarakat Muslim sekarang yang terjadi justru seperti ini. Sejak kecil anak tidak mendapatkan doktrin Islam, justru yang tertanam di kepalanya adalah doktrin sekuler -yang memisahkan antara agama dari kehidupan- karena ia belajar di sekolah-sekolah sekuler. Bahkan yang lebih parah, anak yang sekolah di sekolahsekolah missionaris Kristen dan Katolik dengan berbagai sektenya, akidah mereka terancam dan Iman mereka kian hari kian menipis, sampai akhirnya merekapun murtad dari Islam. Betapa teganya seorang ayah memasukkan anaknya ke "sarang harimau" demi mendapatkan pendidikan modern. Sekolah-sekolah missionaries itu 
bukan hanya tidak memberikan pendidikan Islam kepada anak-anak Muslim, bahkan menjadikan mereka sebagai mangsa untuk penyebaran misi mereka. Sumber-sumber informasi mengatakan, justru anak-anak Muslim itu yang disuruh untuk memimpin doa Kristen di kelasnya.

Rasul Saw. mengajarkan kepada Ibnu 'Abbas, agar senantiasa memelihara aturan-aturan yang sudah ditetapkan oleh Allah Swt. tidak melanggar batasan-batasanNya. Kalau ini dilakukan, niscaya Allah akan memeliharanya juga. Dan jika Allah dijaga dalam arti hukumhukum-Nya ditaati, maka pada saat manusia membutuhkan bantuan Allah, maka Allah senantiasa di hadapan-Nya, menolong kesusahannya, meringankan bebannya.

Pada riwayat lain disebutkan : "Kenalilah Allah di waktu senang, niscaya Dia akan mengenalmu di waktu susah." Maksudnya bila di waktu senang, manusia tetap ingat pada Allah -dan ini biasanya sulit, karena tabiat manusia, bila senang, ia lupa dengan yang memberi nikmat- maka di waktu susah dan sulit, Allah akan menolongnya.

Pelajaran seperti ini memang sangat tepat diajarkan kepada anak. Psikologi anak mudah menerima pendidikan seperti ini dan dengan bahasa seperti hadits ini. Yang diharapkan darinya ialah, doktrin tersebut tertanam dalam benaknya hingga ia tua. Pada waktu ia dewasa ia tetap teringat bahwa apabila seseorang ingin senantiasa mendapat penjagaan dari Allah maka ia harus juga menjaga Allah Swt dalam kesehariannya.

Rasulullah Saw. mengajarkan di dalam hadits ini dasar-dasar aqidah, yaitu tempat meminta hanya kepada Allah Swt. Tempat mengadu hanya Allah Swt. Manusia tidak pantas mengadukan masalahnya kepada manusia apalagi kepada Jin, sementara ia tidak mengadu kepada Zat Yang Menciptakannya. Manusia tak layak meminta bantuan kepada makhluk Allah, apalagi kepada musuh Allah seperti syaitan, padahal kepada Allah ia tidak meminta bantuan. Inilah pelajaran penting dalam aqidah. ${ }^{4}$

Riwayat lain mengenai hadits ini memberikan tambahan penjelasan bahwa hidup ini ibarat berlayar di lautan, kadang airnya tenang, kadang ombaknya besar. Hidup ini tidak selamanya konstan. Kesusahan tidak terus menerus. Kesenangan juga tidak selamanya. Oleh karenanya Nabi Saw. mengajarkan bahwa kemenangan didapat melalui kesabaran. Berkat kesabaran, Allah akan menurunkan bantuan dan pertolongan. Setelah kesulitan, timbullah kemudahan. Bahkan di dalam riwayat tersebut disebutkan, bahwa kemenangan sering didahului oleh penderitaan. Orang yang ingin berhasil dan sukses 
mencapai cita-citanya, ia harus berjuang menapaki jalan kesuksesan itu dengan segala kepahitan dan penderitaan. Bila ia sabar dalam kepahitan itu, maka di depannya kesuksesan telah menunggu. Tetapi bila ia tidak sabar dan mundur dari jalannya, ia akan gagal untuk meraih cita-citanya. ${ }^{5}$

\section{Materi Pendidikan Qur'an}

1 Hadis Tentang Materi Pendidikan Qur'an

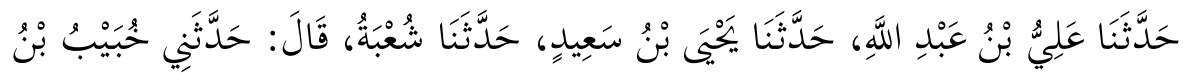

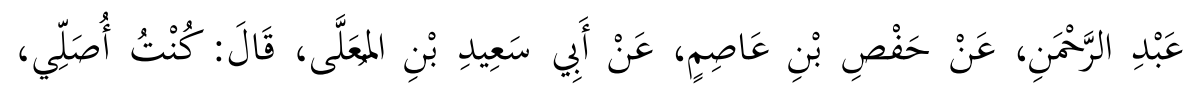

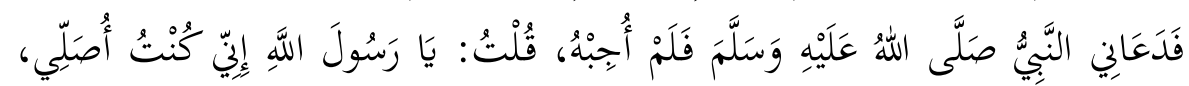

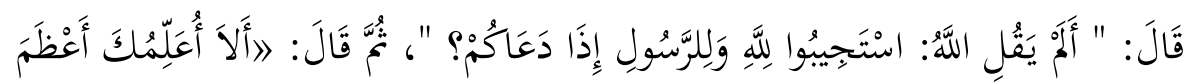

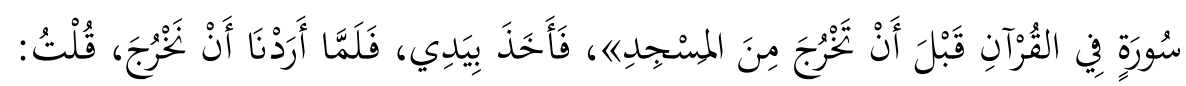

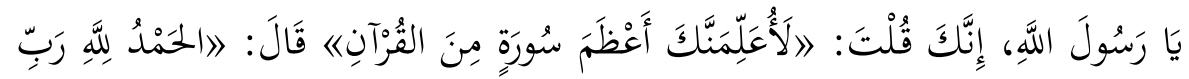

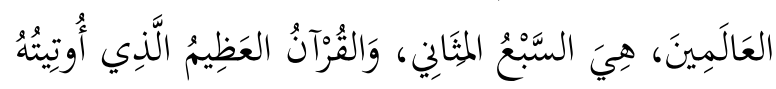

Diriwayatkan dari 'Ali bin Abdullah, diriwayatkan dari Yahya bin Said, dari Syu'aib berkata: Diriwayatkan pada ku dari Hubaib bin 'Abdurrahman, dari Hafs bin 'Ashim, dari Abu Sa'id bin Mu'alla berkata: "Aku sedang shalat kemudian Rasulullah memanggilku, maka aku tidak bisa menjawabnya. Lalu aku berkata, "Wahai Rasulullah Saw tadi saya sedang shalat. Kemudian beliau bersabda, "Bukankah Allah pernah berfirman jawablah panggilan Allah dan Rasul-Nya?, kemudian beliau berkata, maukah kau aku berikan surat yang paling agung dalam Qur'an sebelum keluar dari masjid?

Kemudian beliau menarik tanganku hingga ketika kita hendak keluar aku berkata kepada beliau, "Wahai Rasulullah bukankah engkau akan memberitahuku surat yang paling agung di dalam Qur'an?" Beliau bersabda, "Alhamdulillahi rabbi al- 'alamin, dia adalah tujuh yang diulang dan al-Qur'a al- 'Adzim yang diberikan kepadaku'. (HR. Bukhari)

\section{Kandungan dan Penjelasan Hadis serta Kaitannya dengan Dunia Pendidikan}


Surat al-Fatihah disebut pula Ummu al-Qur'an, dinamakan demikian karena surat al-Fatihah adalah pembuka dalam al-Qur'an. Ibnu Hajar dalam Fathul Bari menjelaskan maksud dari pada surat yang agung adalah besarnya pahala yang di dapat karena membaca alFatihah meskipun banyak surat lain yang lebih panjang darinya karena al-Fatihah adalah surat yang selalu dibaca dalam shalat baik shalat fardhu atau shalat sunnah karena itulah surat al-Fatihah disebut alsab'u al-mastani.

Dalan mendidik anak, asupan pertama terbaik bagi mereka adalah memperdengarkan dan membacakan ayat suci Al-Qur'an. Usahakan mereka menghafal Qur'an sejak dini agar jiwa mereka tumbuh bersama kesucian Qur'an. Sel-sel otak yang jumlahnya milyaran akan tumbuh membentuk gugusan sel yang tidak saja rapi, tapi juga hidup dan bercahaya. Otak mereka menjadi cerdas secara inteleksual dan spiritual. ${ }^{6}$ Tak heran jika dalam proses pembelajaran kurikulum saat ini terdapat kompetensi inti (KI) 3, yakni diwajibkan adanya unsur proses kognitif pada anak terhadap ajaran agama Islam khususnya Qur'an karena semua bagian ilmu agama Islam, seperti fiqh, akidah, dll berpedoman pada Al-Qur'an.

\section{Materi Pendidikan Ibadah}

\section{Hadis Materi Pendidikan Ibadah}

Hadis mengenai materi ibadah penulis ambil dari terjemah kitab Riyadushalihin. Adapun bunyi hadis tersebut adalah:

وعن أَبي هريرة - رضي الله عنه - : أنَّ فُقَراءَ المُهَاجِرينَ أتَوْا رسول الله - صلى ألى

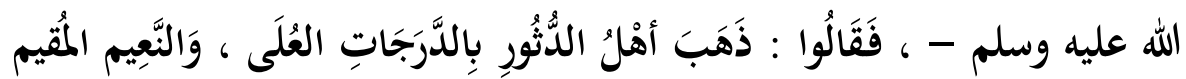

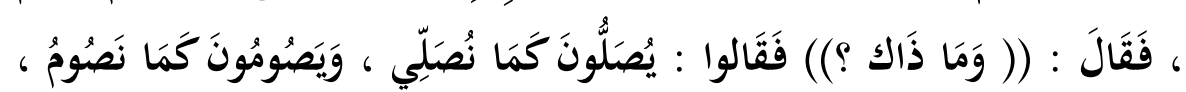

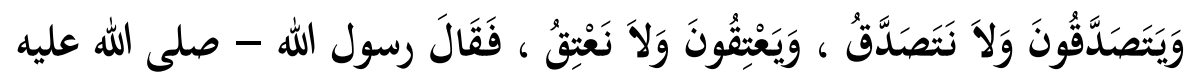

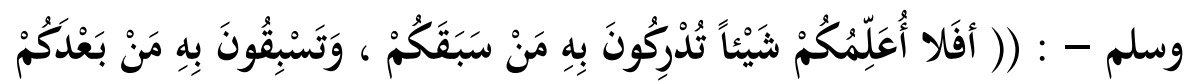

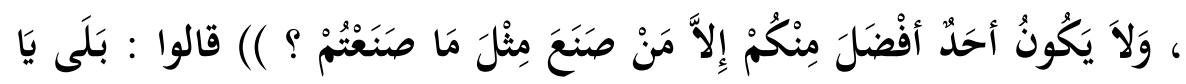

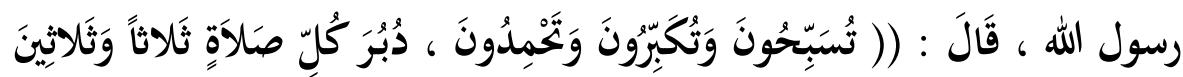

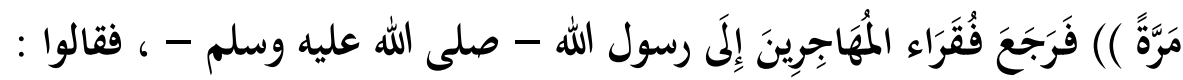




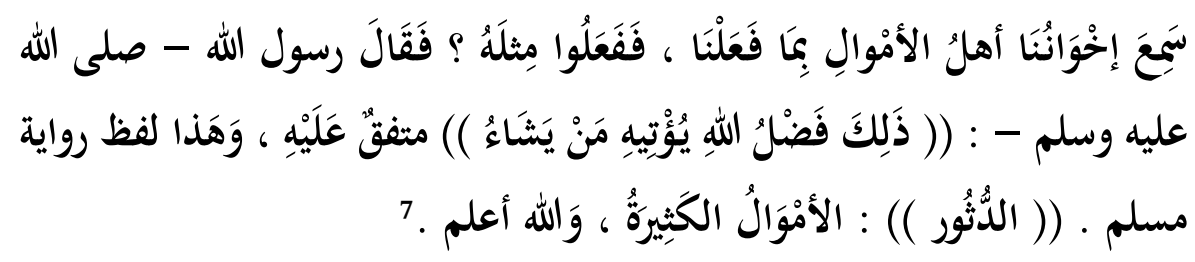

"Dari Abu Hurairah, bahwasannya orang-orang miskin dari kelompok muhajirin datang menemui Rasulullah Saw sambil mereka berkata: "Wahai Rasulullah Saw, orang-orang kaya dan lapang, telah mengalahkan kebaikan dan pahala kami dengan derajat yang tinggi dan kemewahan yang banyak". Rasulullah Saw lalu bertanya: "Bagaimana bisa demikian?" Mereka menjawab: "Mereka melakukan shalat sebagaimana kami shalat, mereka puasa sebagaimana kami juga berpuasa, mereka dapat bersedekah harta namun kami tidak dapat bersedekah, mereka dapat membebaskan budak belian, sementara kami tidak dapat melakukannya". Rasulullah Saw lalu bersabda kembali: "Maukah aku ajarkan kepada kalian sesuatu di mana kamu dapat mendahului, mengalahkan (pahala dan kebaikan) orangorang sebelum kalian dan sesudah kalian, dan tidak akan ada seorang pun yang dapat mengalahkan kebaikan kalian kecuali orang tersebut melakukan sebagaimana yang kalian lakukan?" Mereka menjawab: "Tentu mau ya Rasulullah". Rasulullah Saw bersabda kembali:"Bacalah tasbih (subhanallaah), tahmid (alhamdulillaah) dan takbir (Allahu akbar) setiap selesai shalat (wajib) sebanyak tiga puluh tiga kali". Abu Shalih berkata: "Orang-orang miskin dari kelompok muhajirin lalu kembali lagi menghadap Rasulullah saw sambil berkata: "Kami mendengar bahwa orang-orang kaya itu juga melakukan apa yang telah kami lakukan ya Rasulullah". Rasulullah saw lalu bersabda kembali: "Itu adalah karunia dari Allah, yang Allah berikan kepada orang yang dikehendaki-Nya” (HR. Bukhari Muslim).

Muhammad bin 'Ali Asy-Syaukani rahimahullah mengatakan, "Seorang hamba dilebihkan dari yang lainnya sesuai dengan kehendak Allah. Tidak ada yang mungkin dapat menghalangi pemberian Allah dan tidak mungkin ada yang dapat memberi apa yang Allah halangi. Ketahuilah bahwa kebaikan seluruhnya berada di tangan-Nya. Allahlah yang benar-benar Maha Mulia, Maha Pemberi dan tidak kikir.

\section{Kandungan dan Penjelasan Hadits serta Kaitannya dengan Dunia Pendidikan}


Dari hadist diatas sudah jelas tentang perintah salat atau pendidikan ibadah diberikan sejak dini sehingga ketika usia baligh maka mereka dapat mengamalkannya. Pendidikan ibadah yang dimaksud di sini adalah proses pengajaran, pelatihan dan bimbingan dalam pengamalan ibadah khusus.

Ibadah hendaknya menjadi pendidikan yang paling penting untuk diajarkan kepada murid, terutama ibadah wajib. Ibadah wajib diantaranya adalah salat dan puasa ramadhan. Hendaknya ada penegasan yang maksimal dalam pendidikan ibadah wajib.

Kaitannya dengan dunia pendidikan adalah proses penegasan dalam melatih ibadah dapat diartikan sebagai pengertian bahwa murid tidak boleh menyepelkan hal- hal yang wajib untuk dilakukan. kebiasaan ini akan mereka bawa dalam hal- hal wajib lainnya yang tidak ada kaitannya dengan ibadah wajib, seperti ketika hendak sekolah mereka wajib untuk mandi, tidak terlambat dan mematuhi peraturan- peraturan lainnya disekolah.

\section{E. Materi Pendidikan Fiqih}

\section{Hadis Pentingnya Materi Fiqih}

Sabda Nabi Saw :

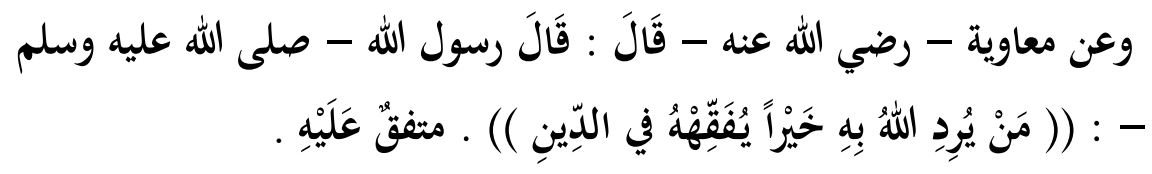

Dari Mu'awiyah ra. katanya: "Rasulullah saw. bersabda: "Barang siapa yang dikehendaki oleh Allah untuk memperoleh kebaikan, maka Allah membuat ia menjadi pandai dalam hal keagamaan." [Muttafaq 'alaih] ${ }^{8}$

\section{Kandungan dan Penjelasan Hadis serta Kaitannya dengan Dunia Pendidikan}

Hadits ini menunjukkan salah satu keutamaan ilmu agama yang paling besar. Disebutkan di situ bahwa ilmu yang bermanfaat merupakan tanda akan keberuntungan seorang hamba, dan tanda bahwa Allah menghendaki kebaikan dengannya. ${ }^{9}$ 
Fikih (pemahaman) dalam masalah agama Islam mencakup pemahaman tentang dasar-dasar keimanan, syariat dan hukum-hukum Islam dan hakikat ihsan. Karena agama ini meliputi ketiga hal tersebut, sebagaimana dalam hadits kisah Jibril tatkala bertanya kepada Nabi shallallahu 'alaihi wa sallam tentang iman, Islam dan ihsan, Nabi menjawab dengan memberikan batasan-batasannya. Di situ Nabi memaknai iman dengan dasar-dasar Iman (rukun Iman) yang enam, dan memaknai Islam dengan rukun-rukunnya yang lima dan memberikan pengertian tentang Ihsan dengan mengatakan: "Yaitu kamu menyembah Allah seolah-olah melihat-Nya, dan apabila kamu tidak melihat-Nya, maka sesungguhnya Dia Melihatmu" .

Maka masuk dalam pemahaman agama ini adalah mendalami berbagai permasalahan akidah, dengan mengikuti jalannya kaum salaf serta mewujudkannya dalam kehidupan baik lahir maupun batin. Juga mengetahui mazhab-mazhab para penentang akidah tersebut, disertai dengan mengerti dari mana bentuk penentangannya terhadap AlQur'an dan Sunnah.

Termasuk juga pemahaman dalam ilmu fikih, yang pokok maupun cabang-cabangnya, hukum-hukum mengenai ibadah, muamalah, jinayat (kriminal) dan yang lainnya. Juga mendalami tentang hakikat keimanan, pengertian akan hakikat perjalanan dan suluk menuju kepada Allah yang sesuai dengan Al-Qur'an dan Sunnah. Demikian juga masuk dalam pemahaman agama ini adalah: mempelajari ilmu yang mendukung pemahaman tentang agama Islam seperti belajar bahasa Arab dengan segala macamnya.

Barangsiapa yang Allah kehendaki kebaikan padanya, Allah akan memberikan pemahaman dalam perkara-perkara ini dan membimbing untuknya. Dari hadits di atas juga bisa diambil kesimpulan bahwa orang yang berpaling dari ilmu-ilmu agama ini secara keseluruhan pertanda bahwa Allah tidak menghendaki kebaikan padanya, karena Allah tidak memberikan padanya hal-hal yang bisa dipakai untuk mendapatkan kebaikan yang banyak, dan meraih keberuntungan hakiki. ${ }^{10}$

Hadits ini merupakan dalil yang agung atas upaya tafaqquh fii al-diin (mempelajari ilmu agama). Hal itu tidak akan diberikan kecuali untuk orang-orang yang Allah kehendaki kebaikan yang besar, sebagaimana Dia memberikan arahan kepada orang bodoh, dan menunjukinya ke derajat yang mulia. Al-Fiqh fii al-diin adalah mempelajari kaidah-kaidah Islam dan mengetahui halal-haram. Makna tersiratnya adalah bahwa barangsiapa yang tidak diberikan pemahaman agama maka dia tidak dikehendaki kebaikan oleh Allah Ta'ala. Pemahaman tersirat ini telah ditegaskan dalam hadits 
riwayat Abu Ya'la: "Barangsiapa yang tidak difahamkan (agama) maka Allah tidak peduli dengannya." Hadits ini merupakan dalil yang jelas bahwa kemuliaan Al-Fiqh fii al-Diin (pemahaman terhadap agama) dan orang-orang yang mempelajarinya, di atas segala jenis ilmu dan cendekiawan. Dan yang dimaksud dengannya adalah memahami Al-Kitab (Al-Quran) dan Al-Sunnah.

\section{F. Materi Pendidikan Keterampilan}

\section{Hadis Pentingnya Materi Keterampilan}

Setiap hari Uqbah bin Amir Al Juhani keluar dan berlatih memanah, kemudian ia meminta Abdullah bin Zaid agar mengikutinya namun sepertinya ia nyaris bosan. Maka Uqbah berkata, "Maukah kamu aku kabarkan sebuah hadits yang aku dengar dari Rasulullah shallallahu 'alaihi wasallam?" Ia menjawab, "Mau." Uqbah berkata, "Saya telah mendengar beliau bersabda:

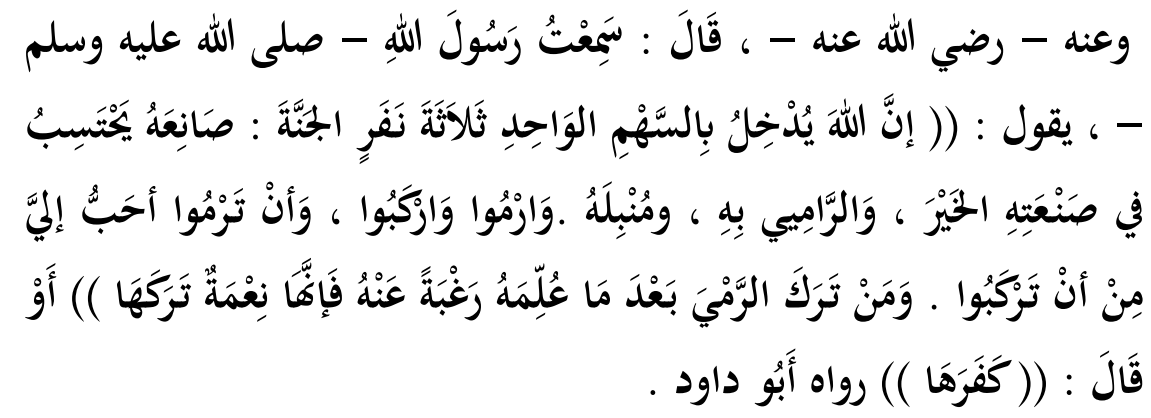

Dari Abu Uqbah bin Amir Al-Juhanniy ra, ia berkata: Saya mendengar Rasulullah Saw bersabda: "Sesungguhnya Allah akan memasukkan tiga orang kedalam syurga dikarnakan satu panah, yaitu pembuatnya yang sewaktu membuat ia hanya mengharapkan kebaikan (pahala), orang yang memanahkan, dan orang yang memberikan anak panah kepada orang yang memanah. Hendaklah kalian selalu berlatih memanah dan berkendaraan, dan berlatih memanah lebih aku sukai, daripada kamu hanya berlatih naik kendaraan. Barang siapa yang meninggalkan/melupakan panahan setelah ia diajari karena benci, maka sikap seperti itu ibarat suatu nikmat yang diingkari”.

4 Kandungan dan Penjelasan Hadis serta Kaitannya dengan Dunia Pendidikan 
Hadits di atas menggambarkan betapa Rasulullah saw sangat menganjurkan agar seorang muslim peduli dengan persiapan untuk berjihad di jalan Allah. Memanah dan berkuda merupakan dua kegiatan yang terkait dengan hal itu. Dan seorang muslim perlu memiliki semangat untuk berjihad di jalan Allah. Mengapa? Karena Nabi saw memperingatkan bahwa raibnya semangat berjihad mengindikasikan hadirnya kemunafikan dalam diri. ${ }^{11}$

Memanah dan berkuda adalah dua keterampilan yang dianjurkan Rasulullah kepada umatnya, karena sarat dengan berjihad dijalan Allah. Namun dalam hal keterampilan ini, Rosulullah saw lebih menekankan kepada umatnya agar lebih memilih untuk berlatih memanah daripada mengendarai kuda atau jika kita tarik pada zaman sekarang, maka latihan menembak juga termasuk keterampilan melatih kefokusan.

Kaitannya dengan sitausi saat ini, bukan lagi masa untuk berperang. Dahulu memanah dan berkuda sangat wajib untuk dikuasai oleh para pemuda khususnya laki-laki. Karena laki- laki adalah pasukan yang harus siap berperang kapanpun apabila mereka dibutuhkan. Berperang adalah cara unuk menyelamatkan kaum dari penderitaan, dan cara untuk mencapai kemakmuran. Dan jika kita kontekstualisasikan dengan kehidupan saat ini, bahwa latihan memanah yang berguna untuk melatih kefokusan bisa dikontekstualisasikan dengan latihan menembak.

Dunia pendidikan saat ini sangat membutuhkan generasigenerasi islam yang dapat menciptakan hal- hal yang dapat bermanfaat bagi manusia lainnya, terutama sesama muslim. Tentu, menciptakan sesuatu yang bermanfaat bagi semama manusia sangat membutuhkan keterampilan. Maka, mengambil pelajaran dari tujuan memanah dan berkuda saat masa perang untuk mencapai kemakmuran, keterampilan melingkupi segala hal yang dapat memberi pengaruh besar bagi keberhasilan, kesejahteraan dan kebangkitan islam. Dalam dunia kurikulum pendidikan saat ini yaitu kurikulum K13 maka keterampilan terdapat pada kompetensi inti (KI) 4. Dimana KI 1 mengenai sikap spiritual, KI 2 mengenai sikap sosial, KI 3 mengenai aspek pengetahuan, dan KI 4 mengenai keterampilan peserta didik.

\section{G. Kesimpulan}

Dari pembahasan diatas, dapat pemakalah simpulkan bahwa: Materi pendidikan yang sangat penting untuk di ajarkan kepada peserta didik yang tertuang dalam hadis diantaranya adalah pendidikan akidah, materi Fiqih, Qur'an, ibadah, dan keterampilan. Jika 
diimplementasikan dengan proses pembelajaran saat ini, yakni kurikulum 2013 terdapat Kompetensi Inti (KI) 1-4, yakni KI 1 mengenai sikap spiritual, KI 2 mengenai sikap sosial, KI 3 mengenai aspek pengetahuan, dan KI 4 mengenai keterampilan peserta didik.

Al-Qur'an dan hadis adalah sumber ilmu yang mencangkup segala materi yang saat ini tertuang dalam buku pelajaran. Materimateri dalam Al-Qur'an dan hadis biasanya disebut dengan materi agama. Lebih dari materi agama, sebetulnya ia sangat berpengaruh dengan dunia pendidikan umum (selain ilmu agama). Pendidikan akidah sangat berpengaruh terhadap kecerdasan berfikir bagaimana melakukan sesuatu yang benar. Materi ibadah sangat berpengaruh terhadap kecerdasan emosional, bagaimana berprilaku yang baik dengan sesama. Pendidikan fiqih sangat berpengaruh terhadap ilmu ekonomi, seperti cara menggadaikan, menyewa dan menabung. materi keterampilan sangat berpengaruh terhadap bakat-bakat yang akan dikembangkan.

${ }^{1}$ Imam Nawawi, Terjemahan Riyadhus Shalihiin, (Jakarta: Pustaka Amani, 1999 ), jilid 1, hal. 90

${ }^{2}$ Imam Nawawi, Terjemahan Riyadhus Shalihiin, jilid 1, hal. 90

${ }^{3}$ Juwariyah, Hadist Tarbawi, (Yogyakarta: Teras, 2010), hal. 45

${ }^{4}$ Juwariyah, Hadist Tarbawi, hal.46

${ }^{5}$ Muhaimi, Wacana Pengembangan Pandidikan Islam, Cetakan II (Surabaya: Pustaka Pelajar, 2004) hal 112

${ }^{6}$ Ahsin Sakho Muhammad, Oase Al-Qur'an Penyejuk Kehidupan, (Jakarta: Qaf Media Kreatif), jilid. 1, hal. 12-13.

${ }^{7}$ Imam Nawawi, Terjemahan Riyadhus Shalihiin, jilid 1, hal. 94

${ }^{8}$ Imam Nawawi, Terjemahan Riyadhus Shalihiin, jilid 1, hal. 97.

${ }^{9}$ Ramayulis, Ilmu Pendidikan Islam. (Jakarta: Kalam Mulia.2002), hal.145

${ }^{10}$ Ramayulis, Ilmu Pendidikan Islam, hal.146

${ }^{11}$ Ramayulis. Ilmu Pendidikan Islam, hal.147

\section{DAFTAR PUSTAKA}

Juwariyah, 2010 Hadist Tarbawi, Yogyakarta: Teras. 
Aini Indah Dwi Cahyani dan Nadra Ulfa, Hadis Materi | 106

Muhaimi, 2004. Wacana Pengembangan Pandidikan Islam, Cetakan II Surabaya: Pustaka Pelajar.

Muhammad, Ahsin Sakho. Oase Al-Qur'an Penyejuk Kehidupan. Jakarta: Qaf Media Kreatif. jilid. 1. hal. 12-13.

Nawawi, Imam. 1999, Terjemahan Riyadhus Shalihiin .Jilid 1, Jakarta: Pustaka Amani.

Ramayulis. 2002. Ilmu Pendidikan Islam. Jakarta: Kalam Mulia. 